\title{
Akıllı Telefondan Yoksun Kalmak: Nomofobi Üzerine Bir Araştırma*
}

Mustafa YILMAZ, Kocaeli Üniversitesi Illetişim Fakültesi Halkla illişkiler ve Tanıtım Bölümü, Doç. Dr. m.yilmaz@kocaeli.edu.tr ORCID: 0000-0003-3320-108X

Aynur KÖSE, Trabzon Üniversitesi İletişim Fakültesi Gazetecilik Bölümü, Doç. Dr. akose@ktu.edu.tr ORCID: 0000-0002-1310-5704

Yusuf Bahadır DOĞRU, Kocaeli Üniversitesi Halkla illişkiler ve Tanıtım Bölümü, Arş. Gör. yusuf.dogru@kocaeli.edu.tr ORCID: 0000-0002-7635-0766

Öz

\begin{abstract}
Yeni iletişim teknolojilerinin gelişimiyle birlikte akullı telefon kullanım oranlarında kayda değer bir artış olmuş, bu araçlar McLuhan'ın yıllar önce öngördü̈̆̈̈̈ gibi bireyin bir uzantısı haline gelmiştir. Akıllı telefon kullanımının günlük hayatta sağladığı pek çok yarardan söz edilebileceği gibi olumsuz olarak nitelendirilebilecek tarafları da bulunmaktadır. Son yıllarda akademik tartışmalarda ve medyada karşılaşılan "nomofobi" kavramı bu bağlamda incelenmeye değerdir. Nomofobi, kısaca "akıll telefondan yoksun kalma korkusu" olarak tanımlanabilir. Bu çalışmada akıllı telefon kullanımının daha çok genç bireylerde yoğunlaştı̆̆ı göz önünde bulundurularak Kocaeli Üniversitesi İletişim Fakültesi'nin 353 öğrencisiyle anket tekniği kullanılarak bir "nomofobi" araştırması gerçekleştirilmiştir. Öğrencilerin nomofobi düzeylerini belirlemeyi amaçlayan bu araştırmada geçerliliği ve güvenilirliği test edilmiş olan Nomofobi ölçeğinden yararlanılmıştır. Araştırma sonucunda öğrencilerin yüzde 40,50'sinin nomofobik olduğunu, Nomofobi Ölçeği'nden aldıkları ortalama puan da nomofobi düzeylerinin ortalamanın üzerinde olduğunu ortaya koymaktadır. Ölçeğin iki alt boyutunu oluşturan "iletişimi Kaybetme ve Bilgiye Ulaşamama" boyutlarında nomofobinin öğrenciler arasında yaygınlaştığ şekilde farklılaştığ tespit edilmiştir. Kadınların "iletişimi kaybetme ve cihazdan yoksunluk" boyutlarındaki nomofobi düzeylerinin anlaml şekilde erkeklerden yüksek olduğu görülmüştür. Katılımcıların özellikle aileleri ve arkadaşlarıla bağlantılarının kesilmesinden ve kendilerine ulaşılamamasından endişe ettikleri saptanmıştır.
\end{abstract}

Anahtar Kelimeler: Nomofobi, Akıllı Telefon, Bağımlıık

\section{Stayıng Away From the Smart Phone: A Research on Nomophobia}

\begin{abstract}
With the development of new communication technologies, there has been a significant increase in the rates of smartphone use, which has become an extension of the individual, as McLuhan predicted years ago. There are many benefits that smart phone use can provide in daily life as
\end{abstract}

\footnotetext{
* Bu makale 14-16 Aralık 2018 tarihleri arasında İstanbul'da düzenlenen Bilişim ve İletişim Teknolojileri Kongresi’nde sözlü sunumu gerçekleştirilen "İletişim Fakültesi Öğrencilerinin Akıllı Telefon Yoksunluk (Nomofobi) Düzeyleri Üzerine Bir Araştırma" başlıklı bildirinin genişletilmiş halidir.
} 
well as negative ones. In recent years, the concept of nomophobia encountered in academic debates and in the media is worth examining in this context. Nomophobia can be defined as fear of lack of smartphone. In this study, considering the fact that the use of smart phones is mostly concentrated in young people, a nomophobia research was conducted with 353 students of Kocaeli University Faculty of Communication using the survey technique. The aim of this study is to determine the nomophobbia levels of the students. In this study Nomophobia scale was used. At the end of the study, it was understood that 40.50 percent of the students are nomophobic and nomophobia levels are above average. It has been determined that nomophobia has become widespread among students in the dimensions of Communication Loss and Unsecretion which constitutes two sub-dimensions of the scale. In addition, it was determined that women's nomophobia levels differed significantly from men. It has been observed that the level of women's loss of communication and device deprivation is significantly higher than that of men. It was found that the participants were concerned that their connections with their families and friends were lost and they could not be reached.

Keywords: Nomophobia, Smart Phone, Addiction

\section{GíRiş}

Günümüz teknolojisinin gündelik hayatımıza getirdiği en büyük yenilik, kullanım alanı her gün genişleyen akıllı telefonlardır. Bu telefonların her geçen gün artan teknolojik özellikleri ile günlük pek çok işimizi bu cihazlarla gerçekleştirmek mümkün hale gelmiştir. Gençler başta olmaz üzere pek çok kişinin yoğun olarak kullandığı akıllı telefonlar, onlar için farklı dünyaların kapısını aralamalarını sağlayan bir anahtar konumundadır. Akıllı telefonlarla yapabildiğimiz birkaç şeyi sıralamak bile bu yaygınlığın nedeni konusunda fikir vermektedir. Her yerden kolayca internete bağlanma, mesajlaşma, elektronik postaları kontrol etme, film izleme, müzik dinleme, Twitter, Youtube, Facebook, Instagram gibi sosyal medya ağlarına bağlanıp sosyalleşme, arama motorları ile pek çok bilgiye kolayca ulaşma, her türlü bilgi ve haber sitesini okuma, oyun oynama, fotoğraf çekme, bankacılık işlerini yapma, mağaza mağaza dolaşmadan alışveriş yapma, yemek sipariş etme gibi gündelik hayatın içinde rutin olarak gerçekleştirdiğimiz pek çok eylemi kolayca gerçekleştirmektedir (Hoşgör, Tandoğan ve Hoşgör, 2017:576). Araştırma sonuçları de bunu net olarak ortaya koymaktadır. TÜIK'in 2018 yılında yapmış olduğu “Hanehalkı Bilişim Teknolojileri Kullanım Araştırması" sonuçlarına göre Türkiye' de cep telefonu/akıllı telefon kullanım oranı \%98,7'ye ulaşmıştır.2004 yılında ise bu oran sadece \%53,7'lik oran göz önünde tutulduğunda geçen 14 senede cep telefonu/akıllı telefon kullanım oranlarının neredeyse ikiye katlandığ görülmektedir (http://www.tuik.gov.tr).

Ancak hiçbir şey tamamen iyi ya da tamamen kötü değildir. Diyalektik anlayıştan hareket edersek her şey karşıtını içinde barındırır. Bu bağlamda akıllı telefonlarda hayatımızı pek çok yönden kolaylaştıran cihazlar olmakla birlikte kullanım yoğunluğuna bağlı olarak birtakım sorunları da beraberinde getirmektedir. Nitekim son dönemde dikkat eksikliğinden, göz problemlerine, psikolojik rahatsızlıklardan fizyolojik ve ortopedik şikayetlere kadar pek çok sağlık sorununda, eğitimde karşılaşılan problemlerde, insan 
ilişkilerinde karşılaşılan sorun ve çatışmalarda neden olarak akıllı telefon kullanım yoğunluğundan bahsedilmektedir. Burada akıllı telefon kullanımının neden olduğu birtakım sorunlar yanında bu cihazlara bağımlılığın ortaya çıkardığı farklı durumlardan da bahsedilmektedir. Bu çalışmanın konusunu oluşturan nomofobi de bunlardan biridir. Nomofobi psikolojide mobil teknolojilerin aşırı ve problemli kullanımlarına vurgu yapan yeni bir kavramdır (Gezgin vd., 2017a:87).

\section{Nomofobi Kavramı Üzerine}

Nomofobi, İngilizce nomophobia (NO MObile PHOBIA) kelimesinden türeyen ve klinik psikolojide bireyin mobil cihazına erişemediğinde veya mobil cihaz üzerinden iletişim kuramadığında yaşadığı istemsiz korku olarak tanımlanmaktadır (Yildirim ve Correia, 2015). Bir diğer tanımda ise mobil telefonu ile iletişime geçememe, mobil telefonundan ayrı kalma ya da internete bağlanama durumunda yaşanan korku olarak ifade edilmektedir (King, Valença ve Nardi, 2010). Nomofobi bireye, telefonunu unuttuğunda, kapsama alanı dışına çıktığında veya telefonunun şarjı bittiğinde ortaya çıkarak bireye kaygı vermeye başlar. $\mathrm{Bu}$ kaygı, bireyin yaşamında günlük işlere yoğunlaşmasını olumsuz biçimde etkilemektedir (Dixit vd., 2010:339). Akıllı telefonlarla her yerde internete erişim imkanına kavuşmak, sosyal medya ve birçok uygulamanın kullanılabilmesi, hızlı bir şekilde iletişime geçme imkânı sunması bireylerin akıllı telefonlarla geçirdiği zamanın artmasına neden olmaktadır. Ayrıca hayatımızda rutin olarak gerçekleştirdiğimiz pek çok eylemin bu akıllı telefonlarla gerçekleştirilmesi cihazlara olan bağımlılığı dolayısıyla da cihazlara ulaşılamama durumunda yaşanan kaygıyı artırmaktadır (Yıldırım ve Correia, 2015; Yıldırım vd., 2016).

Sosyoloji alanındaki işlevselci teorisyenlerden olan Merton (1968), bir yapı ya da şeyin toplumsal sistemin işleyişine yarar sağladığı ölçüde işlevsel olduğu görüşündedir. İhtiyaçlar karşılandığı sürece sistem denge ve uyumunu korur ve o yapı ya da şey sistemin bir parçası olmaya devam eder. Ancak bazen istenen beklenen işlev yanında bu denge ve uyumu bozan işlevler de ortaya çıkabilir. Mesela dinin işlevi toplumu bütünleştirmektir ancak toplumsal çatışmaları artırıcı bir unsur olarak öne çıkıyorsa bu durumda istenen beklenen işlevi dişında istenmeyen beklenmeyen bozuk işlevden bahsetmek gerekir. Bu durumu, asıl işlevi hayatımızı kolaylaştırmak olan akıllı telefonların aynı zamanda teknoloji hastalıklarının da kaynağı haline gelmesiyle bozuk işlev kazanması olarak değerlendirebiliriz.

Nomofobi terimi ilk olarak 2008 yılında İngiltere' de Posta İdaresi'nce yaptırılan bir araştırma sonucunda ortaya çıkmıştır. Araştırmaya katılanların \%53'ünün akıllı telefonlarını kaybettiklerinde, bataryaları bittiğinde veya kapsama alanı dışında olduklarında kendilerini huzursuz hissettikleri saptanmıştır. Cinsiyet açısından değerlendirildiğinde araştırmaya katılan erkeklerin \%58'i kadınların ise \%48'i bu endişeyi yaşadıklarını ifade etmiştir. Ayrıca katılımcıların \%9'u akıllı telefonları kapalı olduğunda kendilerini stresli hissettiklerini belirtmiştir (Bahi ve Deluliis, 2015'den aktaran Erdem vd. 2016:924).

Nomofobi kavramı ile ilgili yapılan akademik çalışmalara bakıldığında; Gezgin ve arkadaşları (2017b) tarafından yapılan çalışmada sosyal ă̆ kullanıcılarının nomofobi durumlarının ortalama düzeyde olduğu tespit edilmiştir. Ayrıca sosyal ağ kullanıcılarının ölçeğin alt boyutlarından biri olan "iletişime geçememe" konusunda yüksek düzeyde 
nomofobiye sahip olduğu ortaya çıkmıştır. Erdem ve arkadaşları (2017) tarafından gerçekleştirilen çalışmada kamu ulaştırma sektörü çalışanları $(\mathrm{N}=202)$ ve üniversite öğrencilerinden ( $\mathrm{N}=265$ ) oluşan iki farklı örneklem kullanılarak, Türkiye'de nomofobinin yaygınlığı araştırılmıştır. Üniversite öğrencilerinin \%54'inin, ulaştırma sektörü çalışanlarının ise \%47'sinin nomofobik olduğu, ayrıca nomofobinin kadınlarda daha yüksek olduğu tespit edilmiştir. Bu araştırma ayrıca yaş ile nomofobi arasında ters yönlü ve anlamlı bir ilişki olduğunu, günlük akıllı telefon kullanma süresi ile nomofobi arasında pozitif ve anlamlı bir ilişki olduğunu ortaya koymuştur. Erdem ve arkadaşları (2016) tarafından gerçekleştirilen bir başka araştırmada ise öğrencilerin \%55'inin nomofobik olduğu ve günde ortalama 6,43 saat akıllı telefonla zaman geçirdikleri bulunmuştur. Öğrencilerin nomofobik olma seviyeleri ile günlük akıllı telefon kullanım süreleri arasında pozitif yönlü, akademik başarıları ile negatif yönlü bir ilişki saptanmıştır.

Tavolacci ve arkadaşları (2015) ise çalışmalarında, Fransız üniversite öğrencilerinin $\% 79,6$ 'sının akıllı telefona sahip olduğunu, her üç öğrenciden birinin nomofobik olduğunu ve kadın katılımcıların erkeklere göre daha fazla nomofobi eğiliminde olduğunu tespit etmişlerdir. Yildirim ve arkadaşları (2015) tarafından 537 üniversite öğrencisinin katılımıyla gerçekleştirilen kümeleme çözümlemesi çalışmasında ise, genç yetişkinlerin yüzde 42,6'sının nomofobik olduğunu tespit etmişlerdir. Nomofobik olanların en büyük korkularınınsa iletişim ve bilgi erişimi ile ilişkili olduğu saptanmıştır. Nomofobi ile ilgili yapılan diğer çalışmalara bakıldığında, Adnan ve Gezgin (2016) tarafından 433 üniversite öğrencisi, Gezgin ve Çakır (2016) tarafından 475 ergen katılımı ile yapılan farklı çalışmalarda nomofobinin ergenler üzerinde ortalamanın üzerinde çıtığı görülmüştür. Cinsiyet değişkenine göre yapılan karşılaştırmada, kız öğrencilerin nomofobisinin erkek öğrencilerden daha yüksek olduğu ve mobil internet kullanım süresi açısından cinsiyetler arasında anlamlı bir fark olduğu saptanmıştır. Ayrıca nomofobi ölçeğinin kullanıldığı bu çalışmalarda iletişime geçilememe ve bilgiye erişememe faktörlerinin gençler arasında yüksek derecede öneme sahip olduğu saptanmıştır.

\section{Araştırma Yöntem ve Örneklemi}

$\mathrm{Bu}$ araştırmanın amacı, aldıkları eğitim gereği iletişim teknolojilerine daha yakın olan iletişim fakültesi öğrencilerinin nomofobi düzeylerini tespit etmektir. Bu amaçla 2018-2019 Eğitim-Öğretim yılı güz döneminde Kocaeli Üniversitesi İletişim Fakültesi'nde öğrenim gören öğrencilere Nomofobi Ölçeği uygulanmıştır. Üç binden fazla öğrencinin eğitim gördüğü KOÜ İletişim Fakültesi'ni \%95 güven aralığında ve +/-\%1,5 hata payına göre temsil eden ve tesadüfi örneklem alma tekniğine göre belirlenmiş 353 öğrenci ile görüşülmüştür. Bu çerçevede çalışma kapsamında herhangi bir kota kullanılmamıştır.

Araştırmada veriler, soru sorma tekniği kullanılarak toplanmıştır. Anket formu iki kısımdan oluşmaktadır. Anketin ilk kısmında demografik bilgiler ve akıllı telefon kullanımına yönelik sorular bulunmaktadır. İkinci kısımda ise Nomofobi Ölçeği (NMP-Q) yer almıştır. Bu ölçek, bireylerin nomofobi düzeylerini ölçmek için veri toplama aracı olarak Yildirim ve Correia (2015) tarafından geliştirilmiş ve yine Yildirim ve arkadaşları (2016) tarafından Türkçe'ye 
uyarlanmıştır. Söz konusu ölçek 20 maddeden oluşmaktadır. Ölçekte "Çevrimiçi Olamama” (5 madde), "İletişimi Kaybetme" (6 madde), "Cihazdan Yoksunluk" (5 madde) ve "Bilgiye Ulaşamama" (4 madde) olmak üzere toplam dört alt boyut vardır. Hoşgör ve arkadaşları (2017) ölçekte yer alan 4. ve 16. soruları birden fazla faktör yüküne sahip olması dolayısıyla ölçekten çıkarmışlardır. Bu araştırmada Hoşgör ve arkadaşlarının çalışması örnek alınarak 18 madde üzerinden araştırma gerçekleştirilmiştir. Veriler beşli Likert tipi dereceli ölçek ile toplanmıştır. Katılımcılara görüşlerini derecelendirme yani görüşlerinin keskinliğini belirtmelerine imkân verecek şekilde "kesinlikle katılıyorum" (5) ile başlayan ve "tamamen katılmıyorum"a (1) giden beşli bir skala sunulmuştur.

\section{Bulgular ve Analiz}

7 demografik bilgi sorusu ve 18 maddelik Nomofobi Ölçeği 'nin uygulandığı örnekleme ilişkin betimsel istatistikler aşağıda sunulmuştur. 18 maddelik ölçeğin uygulandığı grubun cinsiyetine ve yaşına ilişkin dağılım şöyledir.

Grafik 1. Katılımcıların Cinsiyet ve Yaş Dağılımları

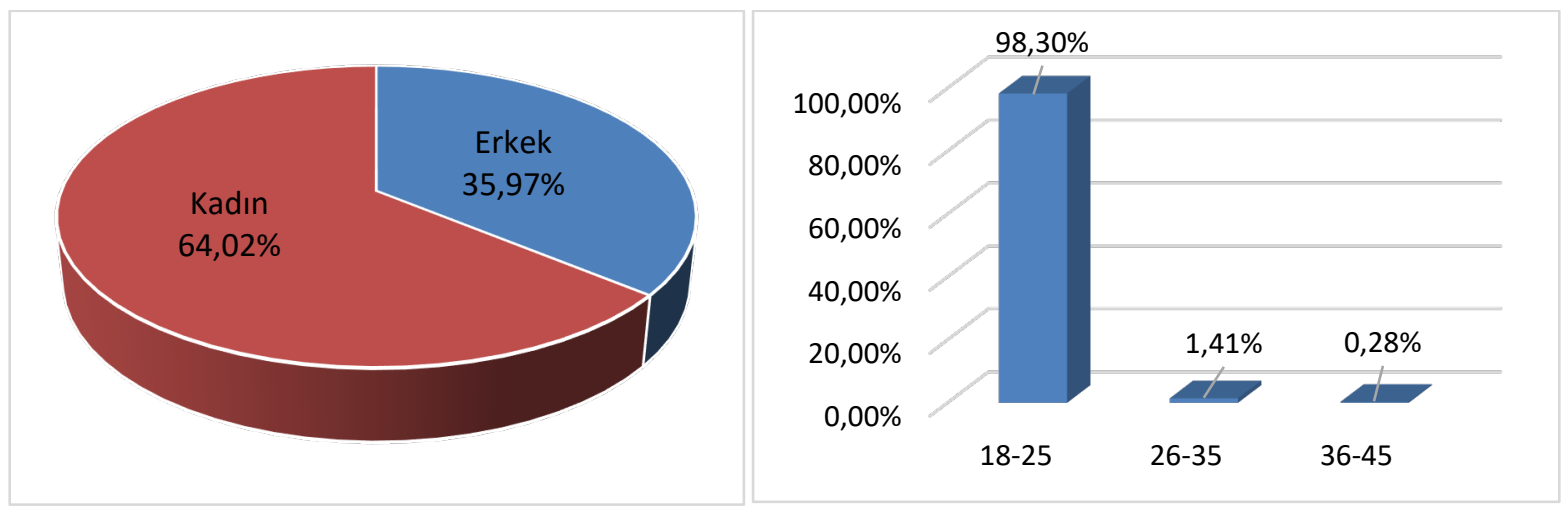

Grafik 1'de görüldüğü gibi, araştırmaya katılan öğrencilerin \%64,02'si (f=226) kadın, \%35,97' si (f=127) erkektir. Katılımcıların yaşlarına ilişkin dağılıma bakıldığında ise örneklemi üniversite öğrencilerinin oluşturması nedeniyle öngörülen bir dağılımla karşılaşılmıştır. Örneklemi oluşturan öğrencilerin \%98,30'ü 18-25 yaş grubunda, \%1,41'i 26-35 yaş grubunda, $\% 0,28$ 'i ise $36-45$ yaş grubundadır. Araştırma kapsamında öğrencilerin sosyo-ekonomik durumları konusunda fikir vermesi açısından aylık gelir düzeyi sorulmuştur.

Grafik 2. Aylık Gelir Dağılımları 


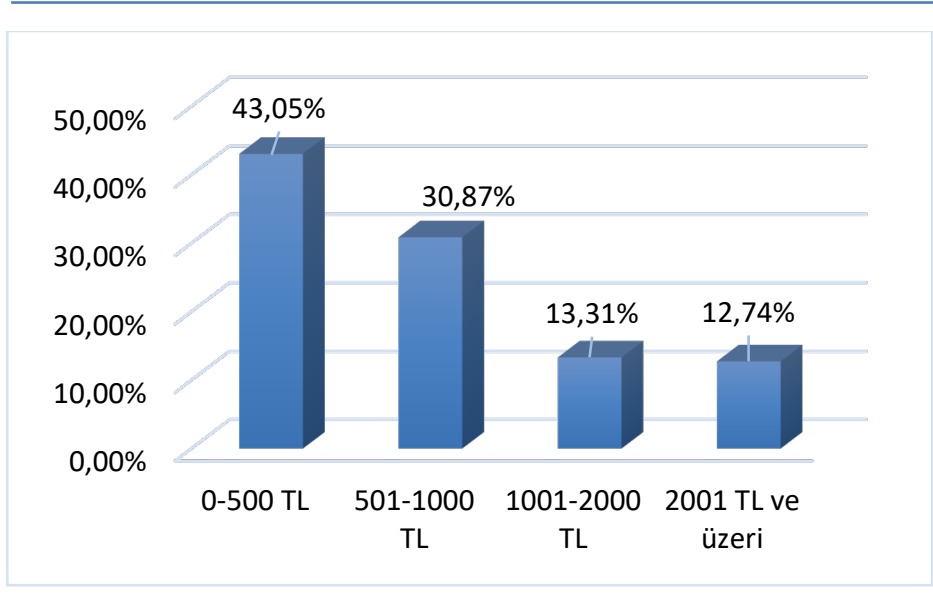

Araştırmaya katılan öğrencilerin gelir durumları incelendiğinde, yığılmanın 0-500 aralığında olduğu görülmektedir (\%43,05, f=152). Öğrencilerin \%30,87'si (f=109) 501-1000 TL, \%13,31'i (f=47) 1001-2000 TL ve \%12,74' $\ddot{u}(\mathrm{f}=45)$ ise 2001 TL ve üzeri gelire sahip olduğunu belirtmiştir. Çalışmada cinsiyet, yaş ve gelire ilişkin soruların ardından öğrencilerin akıllı telefon kullanım alışkanlıklarını anlamaya yönelik beş soru sorulmuştur. Bunlardan ilki kaç yıldır akıllı telefon kullandıklarına ilişkin sorudur.

Grafik 3.Akıllı Telefon Kullanım Oranları (Yıla Göre)

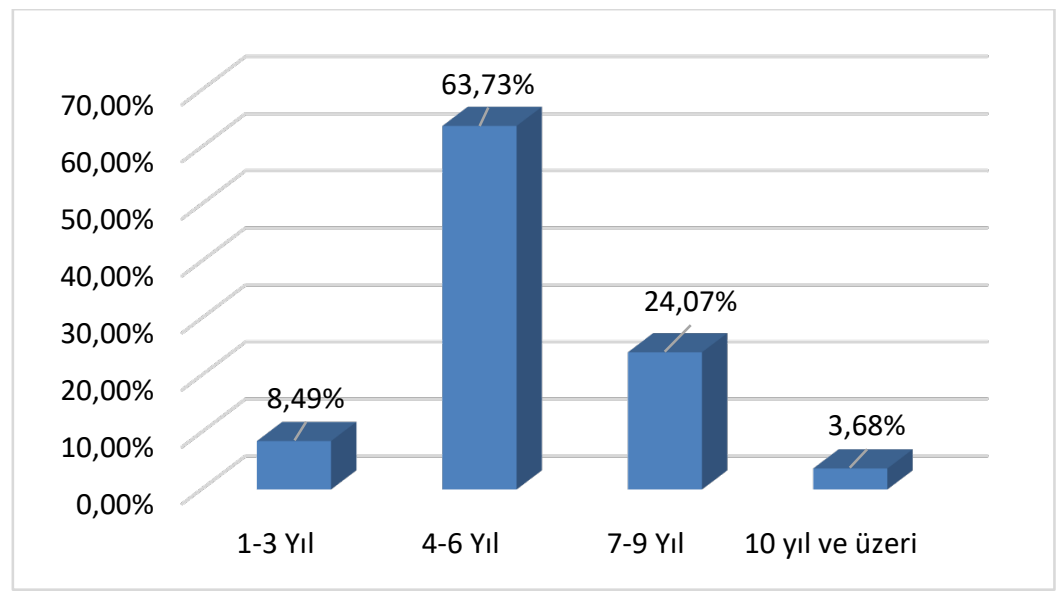

Katılımcı öğrencilerin \%63,73' ̈̈ (f=225) 4-6 yıldan beri akıllı telefon kullandıklarını ifade etmişlerdir. Araştırmaya katılanların \%98,3'ünün 18-25 yaş aralığında olduğu düşünüldüğünde bu beklenen bir durumdur. Burada şaşırtıcı olan öğrencilerin \%24,07'sinin $(\mathrm{f}=85)$ 7-9 yıl arasinda akıllı telefon kullaniyor olmasıdır. 1-3 yıldan beri akıllı telefon kullananların oranı \%8,49 (f=30), 10 yıl ve daha fazla zamandır akıllı telefon kullananların oranı ise \%3,68' dir ( $\mathrm{f}=13)$. Araştırmada öğrencilere günde kaç saat akıllı telefon kullandıkları sorulmuştur. Buna ilişkin veriler aşağıdaki gibidir.

Grafik 4.Günlük Akıllı Telefon Kullanım Süresi 


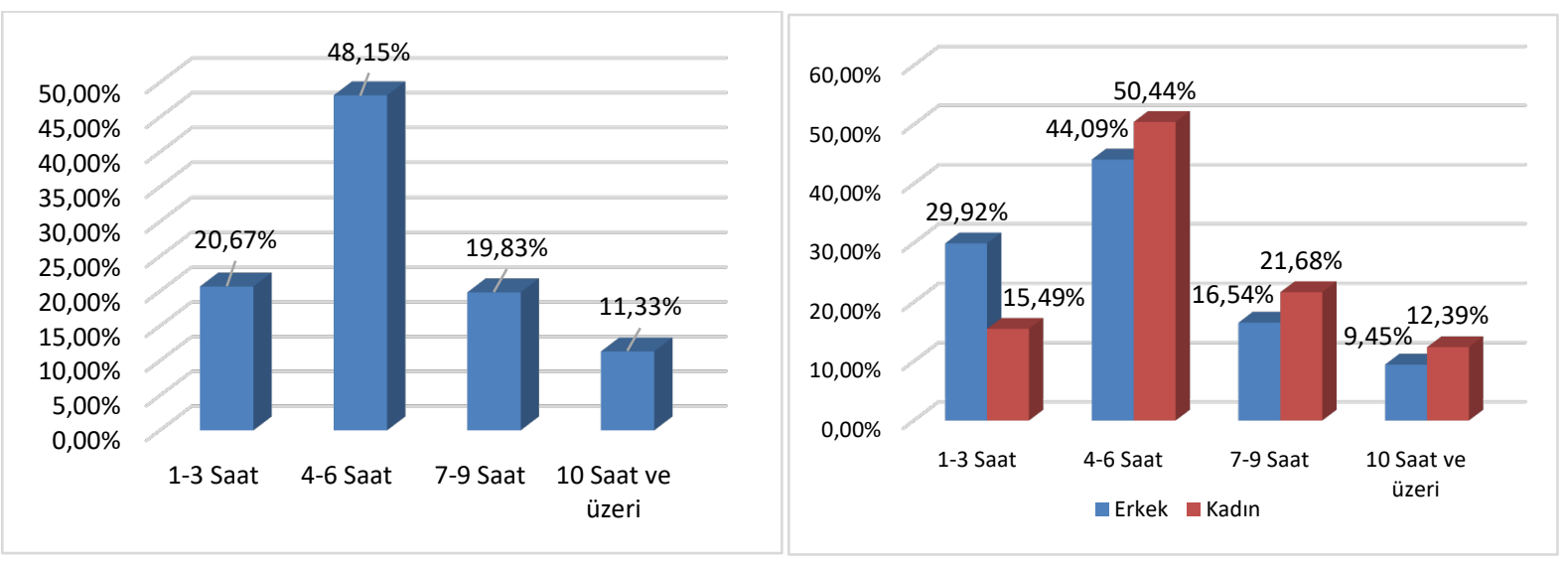

Örneklemi oluşturan öğrencilerin, \%48,15'i (f=170) akıllı telefonunu günde ortalama 4-6 saat arasında kullandığını belirtmiştir. 1-3 saat arasında kullananların oranı, \%20,67 (f=73), 7-9 saat arasında kullananların oranı ise $\% 19,83^{\prime}$ tür ( $\left.f=70\right)$. Katılımcların $\% 11,33^{\prime} \ddot{u}$ ( $f=40$ ) ise günlük ortalama akıllı telefon kullanım süresinin 10 saat ve üzerinde olduğunu belirtmişlerdir. Öğrencilere güne başladıklarında yaptıkları ilk şeyin telefonlarını kontrol etmek olup olmadığ süreleri açısından anlamlı farklarla karşılaşılmıştır ( $2=10,579, \mathrm{sd}=3, \mathrm{p}=0.014<0.05)$. Kadınların 4 saat ve üzeri akıllı telefon kullanma oranları erkeklerden fazla iken 1-3 saat arasında telefon kullanan erkeklerin $(\% 29,92)$ oranı kadınlardan $(\% 15,49)$ fazladır.

Grafik 5. Katılımcıların Akıllı Telefonlarını Kontrol Etme Oranları (Uykudan Uyanıldığında)

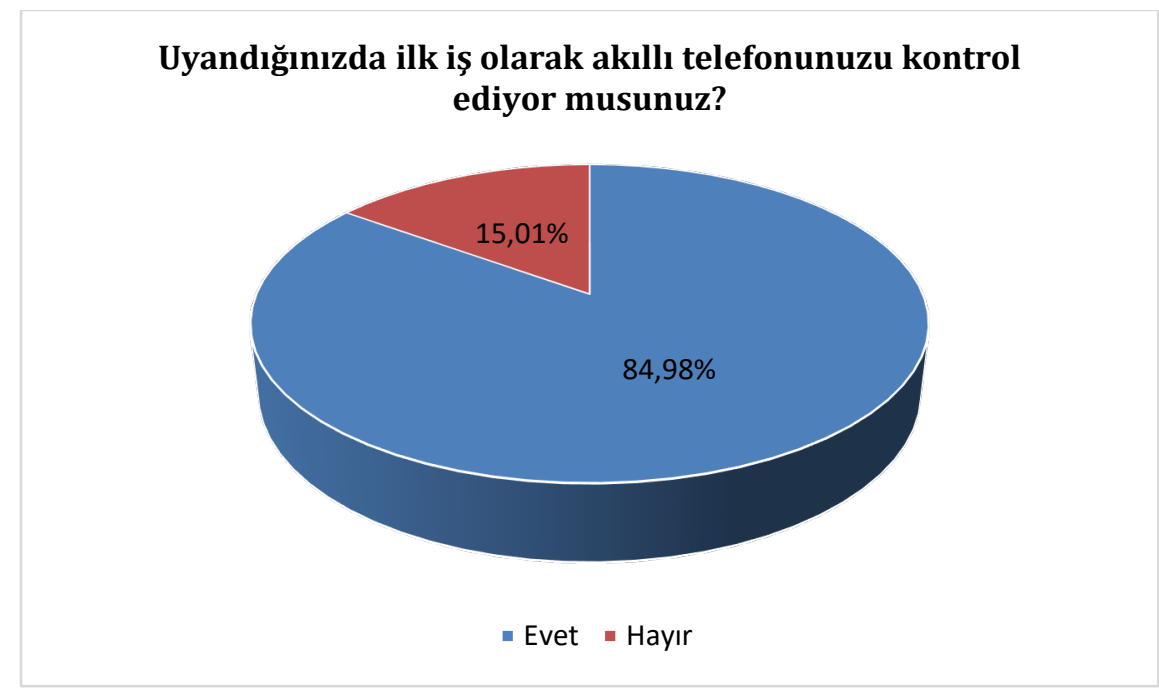

Araştırmaya katılanların verdikleri cevaplar incelendiğinde, öğrencilerin \%84,98'inin ( $\mathrm{f}=300$ ) uyandıklarında ilk iş olarak akıllı telefonlarını kontrol ettikleri belirlenmiştir. İlk iş olarak telefonlarına bakmayanların oranı ise $\% 15,01^{\prime} \operatorname{dir}(\mathrm{f}=53)$.

Grafik 6. Katılımcıların Akıllı Telefonlara Harcama Yapma Oranları 


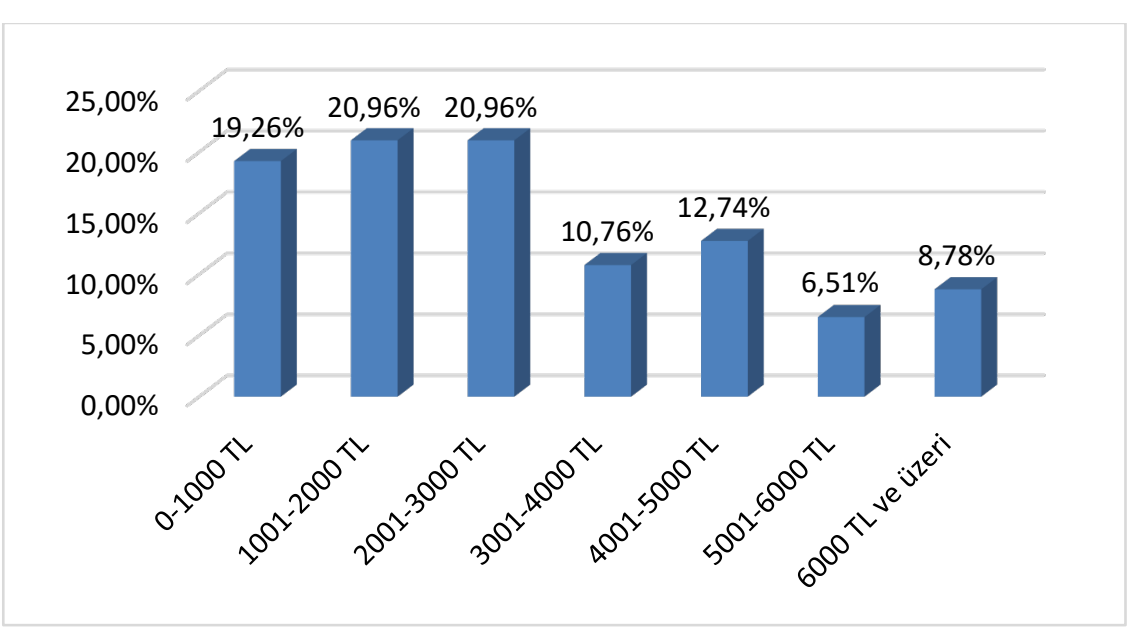

Araştırma kapsamında öğrencilere "Akıllı telefonunuza/telefonlarınıza (cihaza) bugüne kadar ne kadar harcama yaptınız?" sorusuna verilen yantlar incelendiğinde; 1001-2000 TL aralığ 1 ile 2001-3000 TL aralığında harcama yapanların oranının \%20,96 (f=74) ile eşit olduğu görülmüştür. Katılımciların \%19,26'sı(f=68) 0-1000 TL， \%12,74' $\ddot{\mathrm{u}}(\mathrm{f}=45) \quad 4001-5000$ TL, $\% 10,76$ 'sı(f=38) 3001-4000 TL, \%8,78'i (f=31) 6000 TL ve üzeri aralığında ve son olarak \%6,51'i (f=23) 5001-6000 TL aralığında harcama yaptıklarını ifade etmişlerdir.

Grafik 7.Katılımcıların Akıllı Telefonda Kullandıkları Uygulamalara Aylık Harcama Düzeyleri

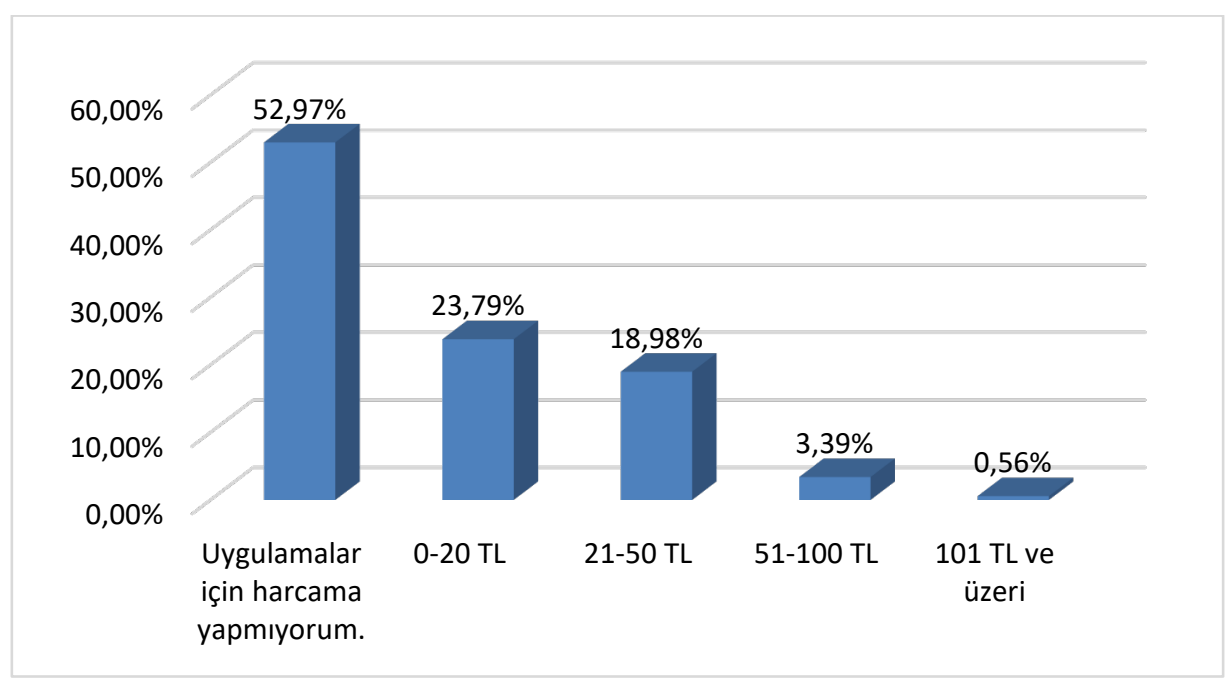

“Akıllı telefonunuz üzerinden kullandığınız uygulamalara aylık ortalama ne kadar harcama yapıyorsunuz?" sorusuna verilen yanitlar incelendiğinde katılımcların \%53,97'si (f=187) uygulamalar için harcama yapmadıklarını ifade etmiştir. Diğer katılımcıların \%23,79'u (f=89) 0-20 TL aralığında, \%18,98'i (f=67) 21-50 TL aralığında, \%3,39’u (f=12) 51-100 TL fiyat aralığında ve son olarak \%0,56'sı (f=2) 101 TL ve üzerinde harcama yaptıklarını belirtmiştir. Araştırmaya katılan bir kişi bu soruya cevap vermemiştir. 
Grafik 8. Katılımcıların Akıllı Telefonların Markalarını Sosyal Statü Göstergesi Olarak Değerlendirme Oranları

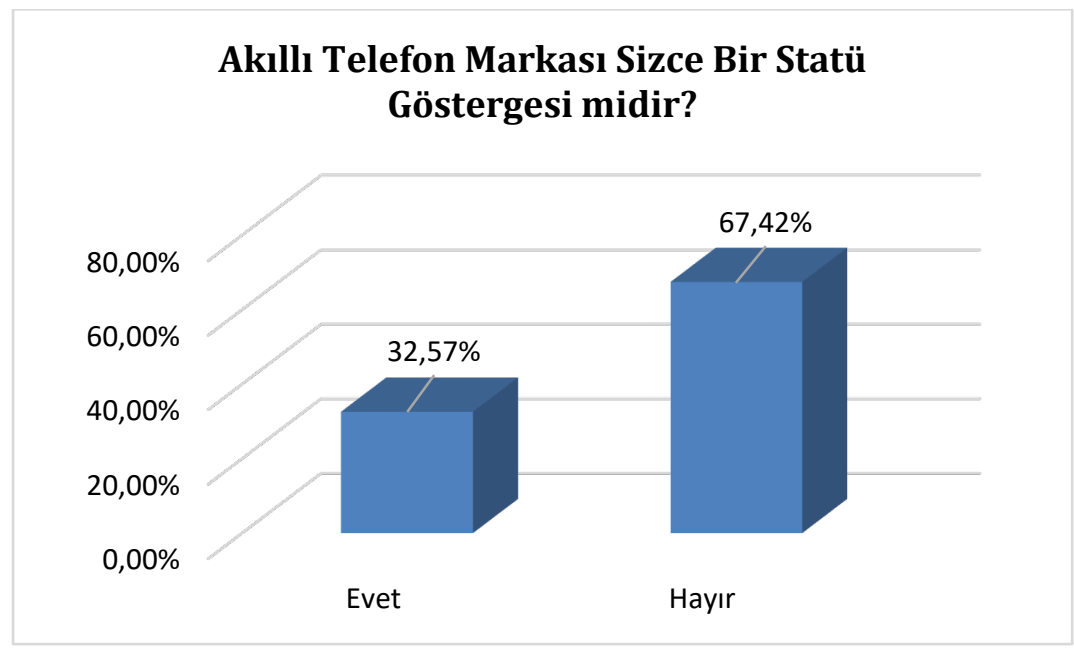

Araştırmada marka ile statü algısı arasındaki ilişkiyi anlamaya yönelik soruya verilen yanıtlara bakıldığında; katılımcıların \%67,42'si (f=238) akıllı telefon markasını bir sosyal statü göstergesi olarak görmediğini belirtmiştir. Geriye kalan \%32,57'lik ( $\mathrm{f}=115)$ kesim içinde akıllı telefonların markası bir sosyal statü göstergesidir. Demografik özellikler ve akıllı telefon kullanım alışkanlıklarına dair sorulara ilişkin betimsel istatistiklerin ardından sıra Nomofobi Ölçeği'nden elde edilen verilerin değerlendirilmesine gelmiştir.

Ölçekteki alt boyutlara ait madde sayıları farklı olduğundan katılımcılara ait toplam puanların boyutlardaki madde sayısına oranı alınarak ortalama puanlar elde edilmiştir. Araştırmada kullanılan Nomofobi Ölçeği'nden ulaşılan ortalama ve standart sapma puanları Tablo 1'de verilmiştir.

Tablo 1. Nomofobi Ölçeği'ne Ait Boyutlar ve Madde Analizleri

Maddeler $\quad \bar{x} \quad S$

\section{Boyut 1: Çevrimiçi Olamama}

Bağlantılarımdan ve çevrimiçi ağlardan gelen güncelleme bildirimlerini 2,45 1,305 takip edemediğim için kendimi tuhaf hissederim.

Elektronik postalarımı kontrol edemediğim için kendimi huzursuz 2,52 1,327 hissederim.

Sosyal medya ve diğer çevrimiçi ağlarda güncel kalamadığım için 2,72 1,303 rahatsızlık duyarım.

Çevrimiçi kimliğinden kopacağım için gergin olurum.

$2,25 \quad 1,286$

\section{Boyut 2. İletişimi Kaybetme}

Ailemle ve/veya arkadaşlarımla iletişim halinde olamadığım için 3,69 1,233 endişelenirim. 
Ailem ve/veya arkadaşlarımla olan bağlantım kesileceği için kendimi 3,77 1,164 huzursuz hissederim.

Ailem ve/veya arkadaşlarım bana ulaşamayacakları için endişelenirim. $\quad 3,78 \quad 1,156$

Ailemle ve/veya arkadaşlarımla hemen iletişim kuramayacağım için kaygı $3,56 \quad$ 1,186 duyarım.

Birinin bana ulaşmaya çalışıp çalışmadığını bilemediğim için gerilirim. $\quad 3,38 \quad 1,207$

Gelen aramaları ve mesajları alamayacağım için kendimi huzursuz 3,46 1,231 hissederim.

Boyut 3. Cihazdan Yoksunluk

Akıllı telefonumun şarjının bitmesinden korkarım.

\begin{tabular}{llllll}
\hline Telefonum çekmediğinde veya kablosuz internet bağlantısına & 3,16 & 1,308
\end{tabular} erişemediğim de sürekli olarak sinyal olup olmadığını veya kablosuz erişim bağlantısı bulup bulamayacağımı kontrol ederim.

Akıllı telefonumu kullanamadığımda, bir yerlerde mahsur kalacağımdan 2,67 1,428 korkarım.

TL kredim bittiğinde veya aylık kota sınırımı aştığım zaman paniğe 2,69 1,384 kapilırım.

\section{Boyut 4. Bilgiye Ulaşamama}

Haberlere (örneğin neler olup bittiğine, hava durumuna ve diğer haberlere) $\quad 3,01 \quad$ 1,250 akıllı telefonumdan ulaşamamak beni huzursuz yapar.

Akıllı telefonumu ve telefonumun özelliklerini istediğim her an 3,03 1,238 kullanamadığımda rahatsız olurum.

Akıllı telefonumdan istediğim her an bilgiye bakamadığımda canım sıkılır. $\quad 3,32 \quad 1,200$

Akıllı telefonumdan sürekli olarak bilgiye erişemediğimde kendimi 3,23 1,266 rahatsız hissederim.

Öğrencilerin Nomofobi Ölçeği'nden aldıkları ortalama puan 3,11 olarak hesaplanmıştır. Buna göre öğrencilerin nomofobi düzeylerinin ortalamanın üzerinden olduğu saptanmıştır. Ölçeğin alt boyutlarının ortalamaları aşağıda sunulmuştur.

Tablo 2. Boyutların Ortalama Puanlarına İlişkin Betimsel İstatistikler

\begin{tabular}{lll}
\hline Alt Boyutlar & $\overline{\mathbf{x}}$ & $\mathbf{S}$ \\
\hline Çevrimiçi Olamama & 2,48 & 1,01 \\
\hline İletişimi Kaybetme & 3,60 & 0,97 \\
\hline Cihazdan Yoksunluk & 2,97 & 1,00 \\
\hline Bilgiye Ulaşamama & 3,14 & 1,00 \\
\hline Toplam & 3,11 & 0,76 \\
\hline
\end{tabular}


Analiz sonucunda "çevrimiçi olamama" ve "cihazdan yoksunluk" boyut ortalamalarının ölçek ortalamasının altında olduğu görülmüştür. "İletişimi kaybetme" boyut ortalamasının $(\bar{x}=3,60)$ diğer boyutlardan fazla olması nedeniyle öğrencilerin bu boyuta katılım düzeylerinin daha yüksek olduğu saptanmıştır. Benzer şekilde "bilgiye ulaşamama” boyutu ortalaması da ölçek ortalamasının üzerindedir.

\section{Ölçek Boyutları Ortalama Puanlarının Cinsiyet Bazında Dağılımı}

Öğrencilerin Nomofobi Ölçeği boyutlarından elde ettikleri puan ortalamalarının cinsiyet bazında dağılımı aşağıda sunulmuştur.

Grafik 9. Nomofobi Ölçeği ortalama puanlarının cinsiyete göre dağılımı

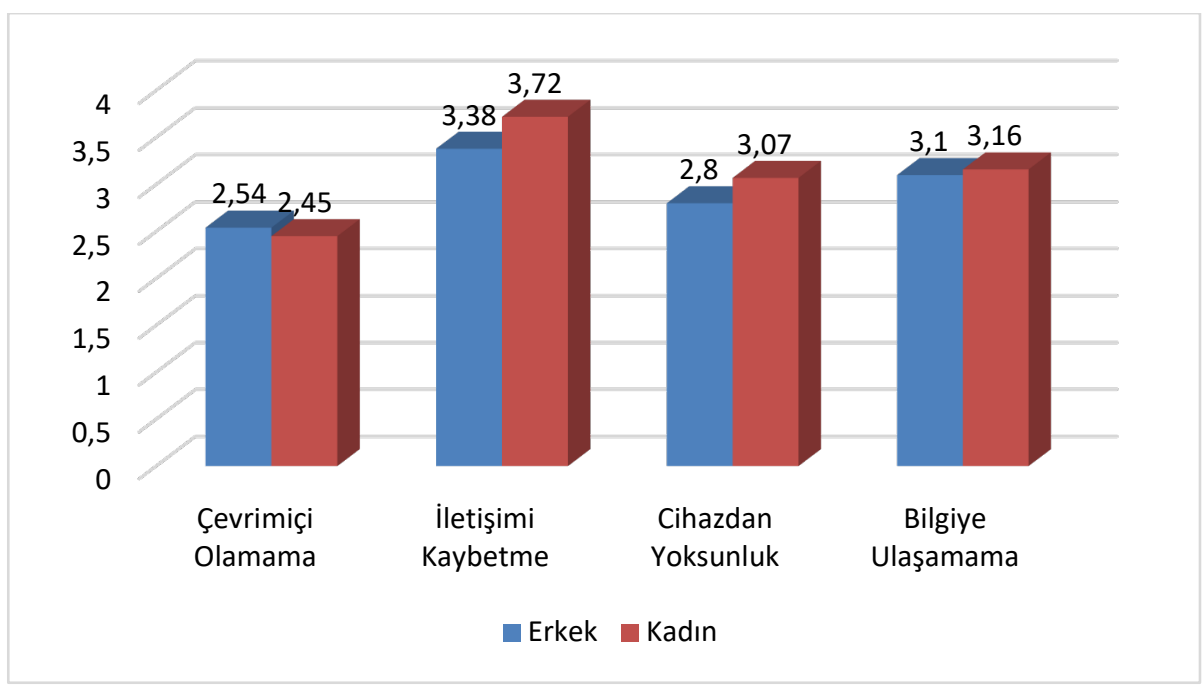

Öğrencilerin Nomofobi Ölçeği'nden aldıkları puanlar cinsiyet değişkenine göre karşılaştıııldığında, puan ortalaması en yüksek olan boyutun her iki cinsiyette de "iletişimi kaybetme" boyutu olduğu saptanmıştır. Kadınların "çevrimiçi olamama" boyutu dişında kalan üç boyutta erkeklerden daha yüksek bir ortalama puana sahip olmalarından hareketle bu boyutlara erkeklerden daha fazla önem verdiklerini söylemek mümkündür. "Çevrimiçi olamama" ise erkeklerin kadınlardan daha fazla önemsedikleri boyut olarak belirlenmiştir.

Nomofobi Ölçeği'nden elde edilen verilerde cinsiyete göre anlamlı bir fark olup olmadığı bağımsız örneklemler için $t$ testi ile incelenmiştir. Öğrencilerin nomofobi düzeyleri açısından kadinlar $(\bar{x}=3,17, s s=0,76)$ ve erkekler $(\bar{x}=3,00, s s=0,76)$ arasinda istatistiksel olarak anlamlı bir 
fark vardır $(\mathrm{t}(351)=-2,01, \mathrm{p}=0,045)$. Buna göre kadınların nomofobi düzeyleri erkeklerden anlamlı şekilde farklıdır. Ardından boyutlar açısından bir karşılaştırma yapılmıştır.

Tablo 3. Nomofobi Ölçeği Puanlarına İlişkin Bağımsız t Testi Sonuçları

\begin{tabular}{lllllll}
\hline Çevrimiçi olamama & $\mathbf{N}$ & $\mathbf{x}$ & $\mathbf{S}$ & SD & $\boldsymbol{t}$ & $\boldsymbol{p}$ \\
Erkek & 127 & 2,54 & 0,99 & 351 & 0,808 & 0,42 \\
Kadın & 226 & 2,45 & 1,02 & & & \\
\hline İletişimi Kaybetme & $\mathbf{N}$ & $\overline{\mathbf{x}}$ & $\mathbf{S}$ & $\mathbf{S D}$ & $\mathbf{t}$ & $\mathbf{p}$ \\
\hline Erkek & 127 & 3,38 & 1,02 & 239,78 & $-3,144$ & $0,002^{*}$ \\
Kadın & 226 & 3,72 & 0,92 & & & \\
\hline Cihazdan Yoksunluk & $\mathbf{N}$ & $\mathbf{x}$ & $\mathbf{S}$ & SD & $\mathbf{t}$ & $\mathbf{p}$ \\
\hline Erkek & 127 & 2,80 & 0,98 & 351 & $-2,493$ & $0,013^{*}$ \\
Kadın & 226 & 3,07 & 1,00 & & & \\
\hline Bilgiye Ulaşamama & $\mathbf{N}$ & $\mathbf{x}$ & $\mathbf{S}$ & SD & $\mathbf{t}$ & $\mathbf{p}$ \\
\hline Erkek & 127 & 3,10 & 1,00 & 351 & $-0,544$ & 0,587 \\
Kadın & 226 & 3,16 & 1,01 & & & \\
\hline * p<0,05 & & & & & &
\end{tabular}

Analiz sonucunda "iletişimi kaybetme ve cihazdan yoksunluk" boyutlarında kadın ve erkeklerde anlamlı bir farkla karşılaşılmıştır $(t(239,78)=-3,144, p=0,002$ ve $t(351)=-2,493$, $\mathrm{p}=0,013$ ). Buna göre kadınların nomofobi düzeyleri "iletişimi kaybetme ve cihazdan yoksunluk" boyutlarında erkeklerden daha yüksektir, kadınlar için bu boyutlar erkeklerden daha fazla önem sahiptir. "Çevrimiçi olamama ve bilgiye ulaşamama" boyutları açısındansa cinsiyet değişkeni anlamlı bir fark yaratmamıştır.

\section{Boyutlara Katılım Düzeyleri}

Ölçekte yer alan boyutlara ilişkin betimsel analizlerin ardından sıra boyut içindeki maddelere yakından bakmaya gelmiştir. Öncelikle her bir boyuta katılım düzeyleri incelenerek en fazla onaylanandan en az onaylanana doğru bir değerlendirme yapılmıştır. Araştırmada öğrencilerin nomofobi düzeylerinin tespitinde kullanılan ölçek beşli Likert tipi dereceli ölçek şeklinde tasarlanmış ve veriler bu şekilde toplanmıştır. Katılımcılara görüşlerini derecelendirme yani görüşlerinin keskinliğini belirtmelerine imkân verecek şekilde "kesinlikle katılıyorum" (5) ile başlayan ve "kesinlikle katılmıyorum"a (1) giden beşli bir skala sunulmuştur. Ancak analiz aşamasında katılma ve katılmama durumları değerlendirilirken yorumlamalarda kolaylık sağlaması açısından, az ya da çok katılma/katılmama durumu tek bir grup olarak ele alınarak toplanmıştır (kesinlikle katıliyorum+katıliyorum=katılma durumu, kesinlikle katılmıyorum+katılmıyorum=katılmama durumu). Öğrencilerin ölçek boyutlarına katılım düzeylerini gösteren veriler aşağıda yer almaktadır. 
Araştırma sonucunda öğrencilerin ölçekteki maddelere katılım düzeylerinin yüzde 40,50 olduğu, katılmama düzeylerinin ise yüzde 36,17 olduğu tespit edilmiştir. Buradan hareketle

Grafik 10. Öğrencilerin "çevrimiçi olabilme" boyutuna katılım düzeyleri

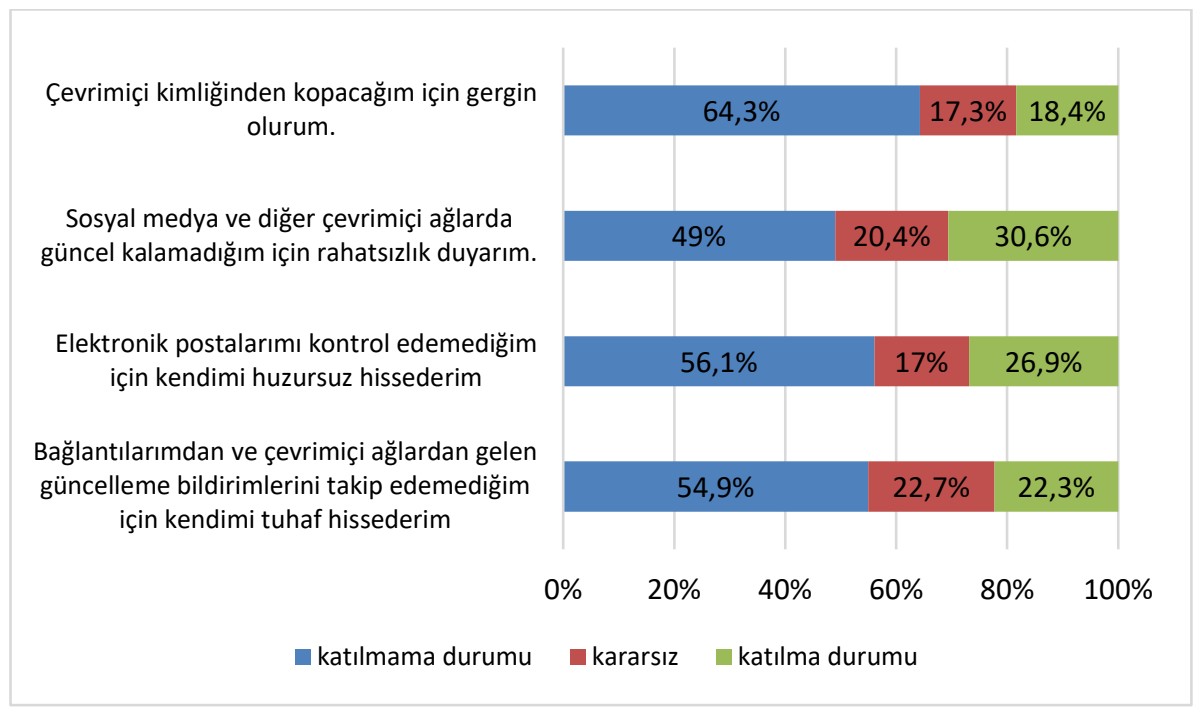

Veriler incelendiğinde "çevrimiçi olabilme" boyutuna katılmama oranı yüzde 56,7, kararsızların oranı yüzde 19,35 ve katılma oranı yüzde 24,55'dir. Bu boyut katılımcılardan diğer boyutlara göre daha az destek almıştır. Öğrencilerin bu boyutta "katılıyorum" diyerek en fazla destek verdikleri madde ise sosyal medyayla ilgilidir $(\% 30,6)$. Katılımcilar sosyal medyada güncel kalabilmeyi e-postalara ve diğer güncellemelere göre daha fazla dikkate aldıklarını ifade etmişlerdir.

Grafik 11. Öğrencilerin "iletişimi kaybetme” boyutuna katılım düzeyleri

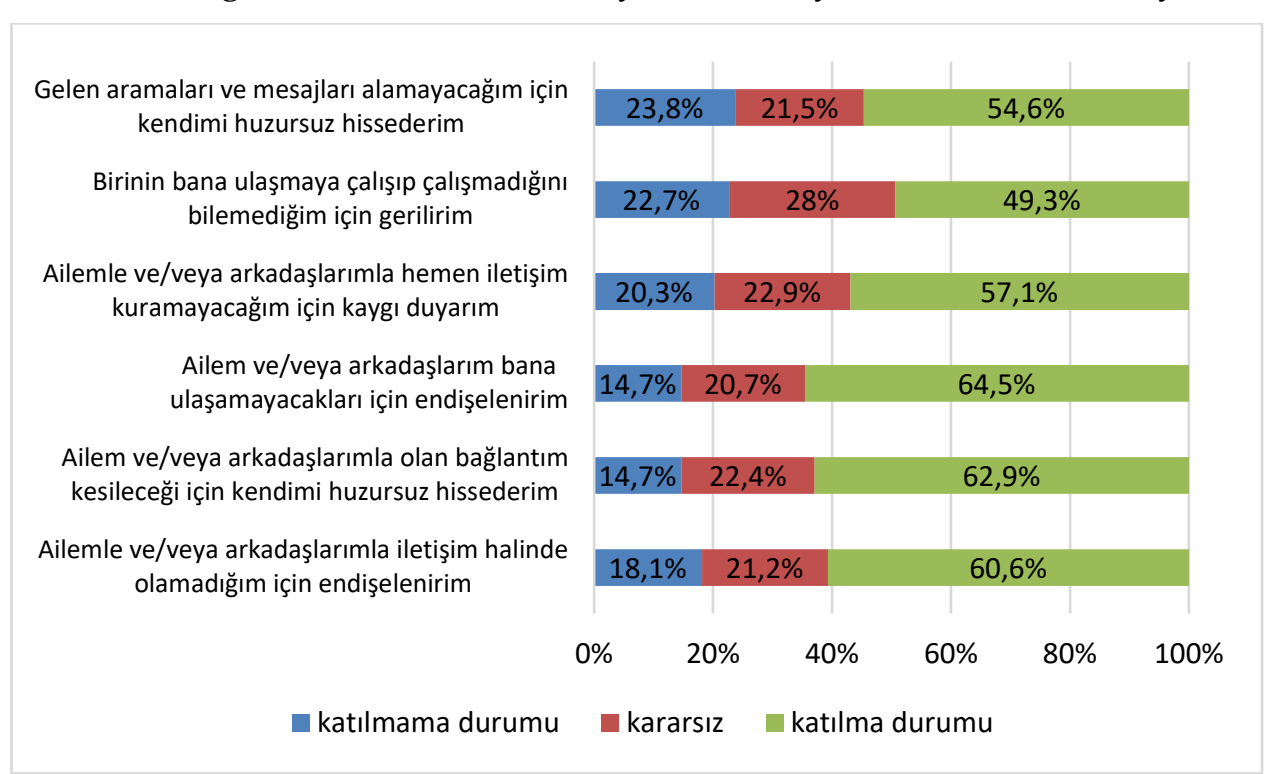

Nomofobi Ölçeğinin "iletişimi kaybetme" alt boyutundaki maddelere verilen yanıtlara bakıldığında, ölçekte katılım düzeyinin en yüksek olan boyut olduğu görülmüştür 
(katılıyorum+kesinlikle katılıyorum \%58,16). Öğrencilerin “Ailem ve/veya arkadaşlarım bana ulaşamayacakları için endişelenirim" $(\% 64,5)$ ve "Ailem ve/veya arkadaşlarımla olan bağlantım kesileceği için kendimi huzursuz hissederim" (\%62,9) maddelerine katılım düzeyinin yüksekliği "iletişime kaybetme" konusundaki endişelerinin yüksek olduğunu göstermektedir. Bu iki madde ayrıca ölçekte en fazla katılım gösterilen maddelerdir.

Grafik 12. Öğrencilerin "cihazdan yoksunluk" boyutuna katılım düzeyleri

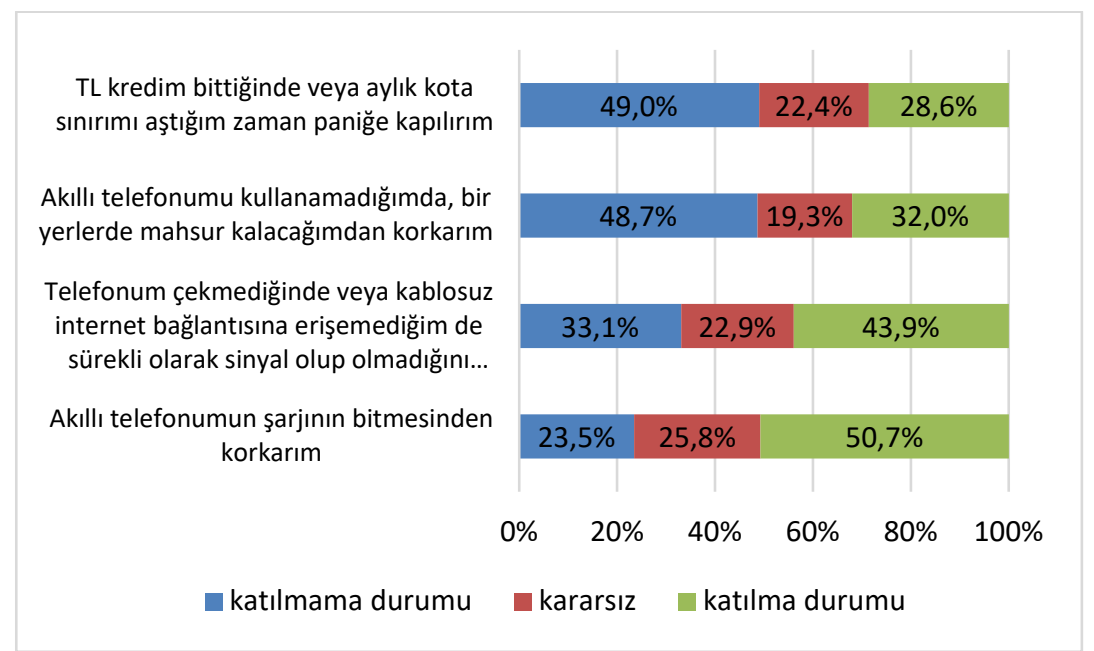

Nomofobi Ölçeğinin "cihazdan yoksunluk" alt boyutunda maddelere verilen yantlara bakıldığında, katılma $(\% 38,8)$ ve katılmama $(\% 38,6)$ durumlarının birbirine yakın olduğu saptanmıştır. Bu boyutta en fazla katılım gösterilen madde "akıllı telefonumun şarjının bitmesinden korkarım” maddesidir (\%50,7). Bu yönüyle öğrenciler için telefonlarını şarjı bittiği için kullanama durumu, bu boyutta en fazla rahatsızlık yaratan durum olarak karşımıza çıkmıştır.

Grafik 13. Öğrencilerin “bilgiye ulaşamama” boyutuna katılım düzeyleri

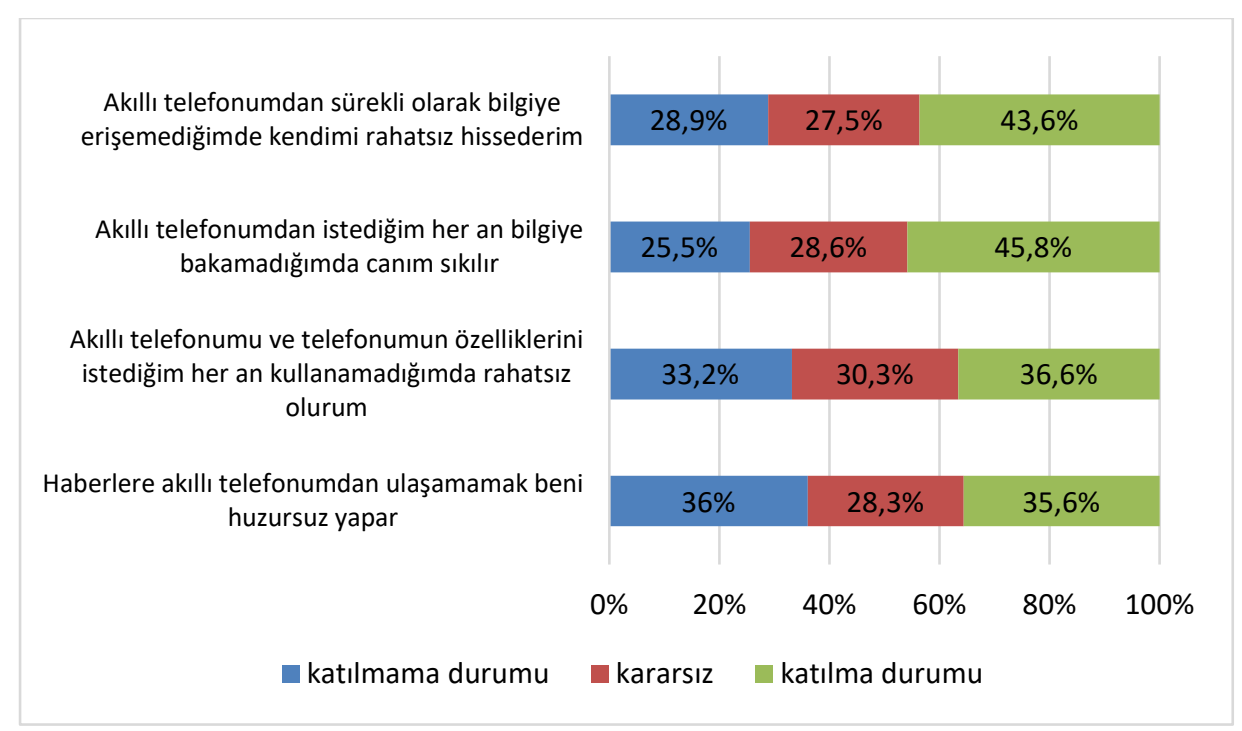


Öğrencilerin Nomofobi Ölçeğinin "Bilgiye Ulaşamama" alt boyutunda yer alan maddelere katılım düzeyleri incelendiğinde genel olarak bu boyuta destek oranının \%40,50 ile katılmama oranından (\%31) yüksek olduğu saptanmıştır. Boyutta en fazla destek alan madde ise "akıllı telefonumdan istediğim her an bilgiye bakamadığımda canım sıkılır" $(\% 45,8)$ ifadesiyle karşılık bulan maddedir. Boyutlar arasında katılım düzeyleri açısından yapılan karşılaştırma sonuçları ise aşağıdaki gibidir.

Grafik 14. Nomofobi Ölçek Boyutlarına Katılım Düzeyi Karşılaştırması

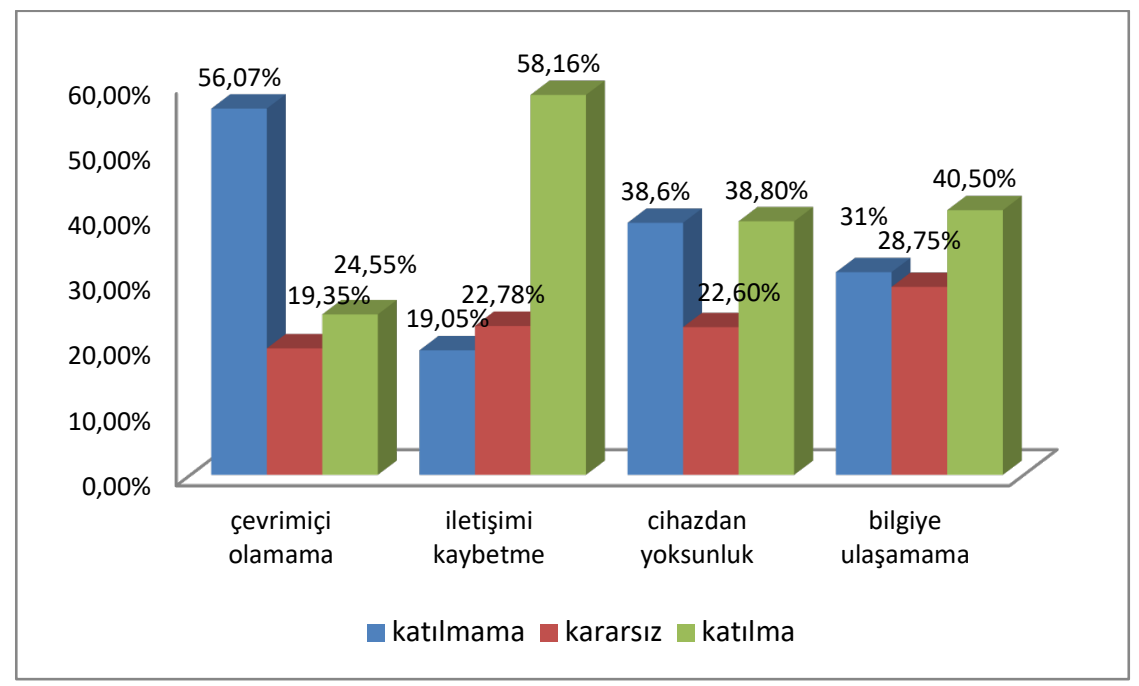

Nomofobi Ölçeği'nde öğrenciler arasında en fazla desteklenen boyut "iletişimi kaybetme" boyutu olurken en az desteklenen boyut ise "çevrimiçi olamama"dır. Bu durumu "iletişimi kaybetme" boyutunda yer alan maddelerden hareketle, akıllı telefonları dünya ile iletişimimizi sağlayan araçlar olarak görmek ve bundan mahrum kalmanın ortaya çıkardığı kayg1 ile açıklamak mümkündür. Bununla benzer şekilde cihazdan yoksunluk boyutunda yer alan telefonun şarjının bitmesinin yarattığı korkuyu dile getiren madde de yüzde 50,7'lik yüksek katılım düzeyiyle benzer bir tutuma işaret etmektedir.

\section{Sonuç ve Değerlendirme}

İletişim teknolojisinin geldiği ve bizleri getirdiği aşama son dönemde olumlu ve olumsuz tarafları ile farklı araştırmalara konu olmaktadır. Bu araştırma teknolojinin hayatımıza kattığ1 korkulardan biri olan nomofobi kavramıyla ilişkilidir. Kısaca akıllı telefondan yoksun kalma korkusu olarak nitelendirilen nomofobinin Kocaeli Üniversitesi İletişim Fakültesi öğrencilerinde yaygınlık durumunu anlamak üzere, Yildirim ve Corerra (2015) tarafından geliştirilen Nomofobi Ölçeği 353 üniversite öğrencisine uygulanmıştır. Araştırma sonucunda katılımcı öğrencilerin yüzde 40,50'sinin ölçekte yer alan maddelere katılmalarından hareketle nomofobik olduğu tespit edilmiştir. Ayrıca öğrencilerin Nomofobi Ölçeği'nden aldıkları ortalama puan da $(3,11)$ nomofobi düzeylerinin ortalamanın üzerinde olduğunu ortaya koymaktadır.

Öğrencilerin nomofobi düzeylerinin özellikle hangi boyutlarda yükseldiği incelendiğinde, "iletişimi kaybetme" ve "bilgiye ulaşamama" boyutlarına verilen yanitların ortalamasının "çevrimiçi olamama" ve "cihazdan yoksunluk" boyut ortalamalarından yüksek olduğu 
görülmüştür. Dolayısıyla öğrencilerin özellikle aile ve arkadaş gibi yakın çevresindeki insanlarla iletişim içinde olma ihtiyacına ve bu ihtiyacın karşılanamaması durumunda ortaya çıkan kaygı ve korkuya işaret eden "iletişimi kaybetme" boyutu ile; akıllı telefonu dünyada olup bitenden haberdar olmayı sağlayan bilgiye ulaşma aracı olarak görme eğiliminin ortaya çıkardığı kaygıyı açıklayan "bilgiye ulaşamama" boyutlarının üniversite öğrencilerinde yüksek düzeyde endişe ve huzursuzluğa neden olduğu sonucuna ulaşılmıştır.

Araştırmada cinsiyet faktörünün nomofobi açısından bir fark yaratıp yaratmadığ incelenmiştir. Buna göre kadınların nomofobi düzeylerinin erkeklerden anlamlı şekilde farklılaştı̆̆ı tespit edilmiştir. Cinsiyet değişkeni açısından boyutlar arasında bir karşılaştırma yapıldığında ise "iletişimi kaybetme ve cihazdan yoksunluk" boyutlarında kadınlar ve erkekler arasında anlamlı bir farkla karşılaşılmıştır. Kadınların "iletişimi kaybetme ve cihazdan yoksunluk" boyutlarındaki nomofobi düzeylerinin anlamlı şekilde erkeklerden yüksek olduğu görülmüştür.

Araştırmada her bir boyuta katılım düzeyleri incelenerek öğrencilerin en fazla destekledikleri ya da en az katılım gösterdikleri boyut ve maddelere daha yakından bakılmıştır. Ölçekte öğrencilerin en fazla destek verdikleri maddelerin "iletişimi kaybetme" boyutunda yer alan ve aile ve arkadaşları tarafından ulaşılamamanın yarattığı endişeye ve korkuya işaret eden maddelerdir. Ölçekte öğrencilerin en az önemsedikleri ve destek verdikleri madde ise "çevrimiçi olamama" boyutundaki çevrimi kimliğinden uzaklaşmanın yarattı̆̆ gerginliğe işaret eden maddedir.

Bu sonuçlar öğrencilerin akıllı telefonları özellikle sosyal çevreyle iletişim ve ardından bilgi ve habere ulaşma aracı olarak gördüklerini ve bu ihtiyaçların giderilememesi durumunda kaygı, endişe ve huzursuzluklarının arttığını ortaya koymaktadır. Bu araştırma Kocaeli Üniversitesi İletişim Fakültesi öğrencileri ile gerçekleştirilmiş bir araştırma olarak bu örneklemde bir sınırlılığa sahiptir. İletişim teknolojilerinin hayatımızdaki önemi göz önünde bulundurulduğunda değişik yaş, eğitim, gelir gruplarında nomofobi düzeylerini ve temel kaygı kaynaklarını tespit etmeye yönelik farklı araştırmalara olan ihtiyaç her geçen gün artmaktadır.

\section{KAYNAKÇA}

Adnan M. \& Gezgin D.M. (2016). Modern Çağın Yeni Fobisi: Üniversite Öğrencileri Arasında Nomofobi Prevalansı, Ankara Üniversitesi Eğitim Bilimleri Fakültesi Dergisi, 49(1), 141-158.

Dixit, S., Shukla, H., Bhagwat, A. K., Bindal, A., Goyal, A., Zaidi, A. K., \& Shrivastava, A. (2010). A Study to Evaluate Mobile Phone Dependence Among Students of a Medical College and Associated Hospital of Central India. Indian Jounal of Community Medicine, 35 (2), 339-341.

Erdem, H., Kalkın, G., Türen, U., \& Deniz, M. (2016). Üniversite Öğrencilerinde Mobil Telefon Yoksunluğu Korkusunun (Nomofobi) Akademik Başarıya Etkisi. Süleyman Demirel Üniversitesi İktisadi ve İdari Bilimler Fakültesi Dergisi, 21 (3), 923-936. 
Gezgin, D.M. \& Çakır, Ö. (2016). Analysis of nomopfobic behaviors of adolescents regarding various factors. Journal of Human Science, 13(2), 2504-2519.

Gezgin, D. M., Şumuer, E., Arslan, O., \& Yıldırım, S. (2017a). Nomophobia Prevalence among Pre-service Teachers: A case of Trakya University. Trakya Üniversitesi Eğitim Fakültesi Dergisi, 7(1), 86-95.

Gezgin, D. M., Şahin, Y. L., \& Yıldırım, S. (2017b). Sosyal Ağ Kullanıcıları Arasında Nomofobi Yaygınlığının Çeşitli Faktörler Açısından İncelenmesi. Eğitim Teknolojisi Kuram ve Uygulama, 7(1), 1-15.

Hoşgör, H., Tandoğan, Ö., \& Hoşgör, D. G. (2017). Nomofobinin Günlük Akıllı Telefon Kullanım Süresi ve Okul Başarısı Üzerindeki Etkisi: Sağlık Personeli Adayları Örneği. Akademik Sosyal Araştırmalar Dergisi, 5(46), 573-595.

King, A. L. S., Valença, A. M., \&Nardi, A. E. (2010). Nomophobia: The mobile phone in panicdis order with a goraphobia: Reducing phobias or worsening of dependence? Cognitive and Behavioral Neurology, 23(1), 52- 54

Merton, R. K. (1968). Social Theory and Social Structure. New York: The Free Press.

Tavolacci, M. P., Meyrignac, G., Richard, L., Dechelotte, P., \&Ladner, J. (2015). Problematic Use of Mobile Phone and Nomophobia among French College Students. The European Journal of Public Health, 25 (suppl 3), 206

Yildirim, C., ve Correia A-P. (2015). Exploring the dimensions of nomophobia: Development and validation of a self-reported questionnaire. Computers in Human Behavior, 49, 130-137.

Yildirim, C., Sumuer, E., Adnan, M. Ve Yıldırım, S. (2016). A Growing Fear: Prevalence of Nomophobia Among Turkish College Students. Information Development, 32(5) 1322-1331.

http://www.tuik.gov.tr/PreTablo.do?alt_id=1028(Erişim Tarihi 02.11.2018) 